\title{
Crimean Wine Market Enterprises: Challenges and Opportunities
}

\author{
Rena Timirgaleeva ${ }^{1}$, Marina Matyunina ${ }^{1}$, Marina Shostak $^{2} \&$ Boris Makarenko $^{3}$ \\ ${ }^{1}$ Department of Economics and Management, V.I. Vernadsky Crimean Federal University, Simferopol, Russia \\ ${ }^{2}$ Department of Management and Touristic Business, V.I. Vernadsky Crimean Federal University, Simferopol, \\ Russia \\ ${ }^{3}$ Administration of the Khostinsky intracity district of Sochi, Sochi, Russia \\ Correspondence: Marina Matyunina, Department of Economics and Management, V.I. Vernadsky Crimean Federal \\ University, Simferopol, 4, Akademika Vernadskogo Ave., 295007, Russia. Tel: 7-978-021-1447. E-mail: \\ matyuninamarina@meta.ua
}

Received: June 20, 2019

Accepted: August 6, 2019

Online Published: August 28, 2019

doi:10.5430/rwe.v10n3p32

URL: https://doi.org/10.5430/rwe.v10n3p32

\begin{abstract}
The article explores the regional aspects of the Sevastopol wine business enterprises' development by means of an analysis of the wine business market. An assessment of the potential of the viticulture and winemaking agro-industrial subcomplex was made taking into account the new economic conditions: the integration of the region into the Russian economic space, and the need to implement the import substitution policy. The production indicators of the five largest enterprises in this field were analyzed. The presence of a large variety of services and products in the field of winemaking and the potential resources of viticulture were distinguished. The study showed that viticulture and winemaking, the production and sale of wine materials have always been among the most attractive branches of the agro-industrial complex of the Crimea, where the largest of the leading regions of viticulture is the federal city of Sevastopol. The conducted assessment made it possible to identify the high potential of the regional industry that can be effectively implemented, provided that the wine cluster and terroir winemaking are formed and implemented.
\end{abstract}

Keywords: viticulture, winemaking production, terroir, economic cluster, wine market, import substitution

\section{Introduction}

The purpose of this article is to assess the potential of the viticulture and winemaking subcomplex of the agro-industrial complex of the federal city of Sevastopol, taking into account the new economic conditions (integration of the region into the economic space of the Russian Federation, the need to implement import substitution policies at the regional level) and substantiate the need to form a mechanism for the development of viticulture and winemaking production and sales markets, increasing the investment attractiveness of the region.

Achieving the goal of the study is based on solving a number of problems: analysis of the wine business market of the city of Sevastopol; monitoring of the wine market of the city of Sevastopol; identifying the potential of winemaking services and products in the region; the rationale for the formation of a wine cluster; elaboration of a concept of the mechanism for developing viticulture and winemaking production and sales markets for the products, increasing the investment attractiveness of the federal city of Sevastopol.

The research hypothesis suggests that the main unrealized potential of Crimean market growth is wine cluster development together with the implementation of modern terroir winemaking in the federal city of Sevastopol can raise the interest in the Crimea and ensure solutions of regional socio-economic issues, national problems of import substitutuion and increase the investment attractiveness of Crimea. This, in turn, will expand the viticulture and winemaking production and sales markets for wine products, use of the region's resources, scientific and production potential more efficiently.

The paper substantiates the necessity of the wine business' cluster model formation, based on the existence of partnerships between the subjects of the cluster. A mechanism for the development of viticulture and winemaking production and the sales markets of the product was proposed, the implementation of which will increase the investment attractiveness of Sevastopol and will become the basis for implementing the program of the socio-economic development of the city of Sevastopol until 2030. 


\subsection{Research Background}

The literature mainly examines the experience of developing wine-producing countries and practically does not deal with markets that are not wine-making regions. However, these markets may include profitable export markets. The study by Juan Castillo-Valero and Carmen García-Cortijo (2016) aims at exploring one of these markets, investigates the behavior of wine consumers and provides the analysis of the wine market in the Dominican Republic, based on a survey of consumers conducted through supermarkets and liquor stores in the region.

The changes in the wine markets form a competitive scenario of their development. The study by Glyn Wittwer, Nick Berger and Kym Anderson (2003) made it possible to see the growth trends in world wine imports, taking into account all the wines together and certain categories recognized by the world statistics (bottled, draft and sparkling wines), identified on the basis of the analysis of mass trade in wine, re-export of wine, the impact of the trade flows on the trade barriers.

The theoretical and empirical structure of the world multisectoral model of wine, which uses various features of general equilibrium models, is considered interesting for the study (Wittwer et al., 2003). The model is broken down into expanding premium and diminishing non-premium segments of the wine market and shows the impact on the world market of the projected rapid expansion of premium-class wine supply as well as the projected growing consumer preferences worldwide for premium wine.

According to Vasileios Vlachos (2017), over the past decade, there has been a tendency in the world wine market to increase the import of vintage wines from South-East Asia.

Unlike other countries of the south of the European Union, which have already established the traditions of wine production, Greece is the country that has not yet fully used the export potential of the industry. There are directions for the development of the industry aimed at improving its competitiveness and Greece's exit from the economic depression (Fleming, Mounter, Grant, Griffiths, \& Villano, 2014).

The study by David Hojman and Pippa Hunter-Jones (2012) identified two important trends that affect the wine industry in Australia. Firstly, all countries have migrated to higher price segments; secondly, new global producers, as well as Portugal and Spain, have achieved much greater success in increasing their export value than in extracting value in their domestic markets. These circumstances led to the fact that Australian wine producers lost their competitive advantages to some extent during the 2000s. As a result of self-analysis, the necessity of promoting the winemaking regions of Australia, based on more qualitative wines, as well as promoting their quality indicators, is substantiated.

Angela Mariani, Eugenio Pomarici and Vasco Boatto (2012) showed the role of branding in the development of the wine business. Government agencies, associations and winemaking enterprises should understand that the brand of the wine sector contributes to the development of the sector, thus the joint work of all the interested parties should be aimed at improving the production process and the quality of the products, sold in the domestic and international markets.

The development of the wine business in a number of winemaking countries leads to the development of another important industry - wine tourism. However, the role of wine tourism in the development strategies of the wine industry remains unclear (Velikova, Murova, \& Dodd, 2013). The authors explore and differentiate the role of wine tourism in Chile, propose to classify business models of winemaking enterprises based on two development strategies: firstly, enterprises that consider wine tourism as a link in a chain of international, possibly intercontinental relations; secondly, enterprises that consider wine tourism as a survival strategy.

Armand Gilinsky, Sandra Newton and Rosana Vega (2016) emphasized the potential role of labeled food and wine products in the development of a specific rural region, and the mapping of the areas, affected by the phenomenon of gastronomic and wine tourism, allows making a positioning map, based on a comparison of the two variables: the amount of food and wine products and local tourism offer, in order to determine which areas and related products are more suitable for gastronomic and wine tourism.

The current stage of development of the Crimean economy is determined, on the one hand, by the processes of integration into the Russian business system, and on the other, by the need to implement an import substitution strategy. In the context of these processes, the development and improvement of the efficiency of the functioning of the food subcomplexes is an important issue, including the viticulture and winemaking subcomplex as a whole and its structural components.

In the course of elaborating new priority areas for the development of the Crimean Federal District, the need was 
clearly identified to conduct additional research in the development of the wine business as not only the most attractive branch of the region's agro-industrial complex but also an attractive object for the development of wine tourism. These aspects determined the purpose, objectives, and relevance of this study.

Strengthening global geopolitical and economic threats implies a choice of organizational and economic mechanisms and approaches that support the sustainable development of the wine business while minimizing external risks. This can be achieved through the formation of internal growth points that can stimulate domestic demand for domestic products, provide the necessary level of investment and the scale and structure of the viticulture and winemaking production, which is adequate to the increasing level of demand (Timirgaleeva \& Talanov, 2015).

The effectiveness of the import substitution policy in the viticulture and winemaking industry depends to a decisive extent on the degree to which specific features, specializations, capabilities and resource potential of the region are taken into account, where the enterprises of the industry are located.

Paying attention to the previously elaborated State Program for the Development of Agriculture and Processing Industry of the Federal City of Sevastopol for 2015-2020 (approved by the Decree of the Government of Sevastopol dated November 27, 2014 No. 511), it is worth noting that the central place is occupied by the support for viticulture and winemaking. The peculiarities of the climatic conditions of this region form viticulture as one of the most profitable branches of economic management; the profitability index in 2010 is $9.5 \%$, with a tendency to growth (Ministry of Economic Development of Republic of Crimea, 2016). This direction of production is reflected in the 'Concept for the Development of Winemaking in the Federal City of Sevastopol', elaborated in 2015 (Legislative Assembly of the city of Sevastopol, 2015).

This study is aimed at analyzing the state of the production of wine and wine resources in one of the regions of Crimea, the federal city of Sevastopol, where all natural conditions are created for the production of viticulture and winemaking products similar to the European ones, which, on the one hand, contributes to the implementation of the import substitution policy of Russia, on the other hand, it is aimed at increasing the level of attractiveness of the tourist territory, and generally favors the development of interest in the Crimea in the domestic and international market in the framework of the wine tourism.

\section{Method}

In the process of research, a complex of methods was used, in particular, structural and analytical methods when investigating the competitiveness criteria and the structure of viticulture management in Crimea on the first stage of market analysis.

At the next stage, we held a comparative analysis for descriptive and used historical method, systematization, specification, structural decomposition and generalization of complete wine business cycle beginning from production and preparation of raw materials to processing and pricing strategies to present theoretical foundations for clustering and determining the potential of wine terroir winemaking. The parametres analysed are market share and occupied market segments (from table to premium, from farms to restaraunts and warehouses), volume of production, and pricing strategies. Decomposition and the integrated approach based on identifying cause-effect relationships, and the graphical method were used when conceptualizing the management of the development of viticulture and winemaking production and sales markets of the product (wine), increasing the investment attractiveness of the region, the methods of its quantitative evaluation.

Statistical, graphical, retrospective analysis, correlation analysis, structural and system-comparative analysis were used in diagnosing the prerequisites for the development of viticulture and winemaking production and sales markets of the products, increasing the investment attractiveness of the region and assessing the compliance of the initial state of its potential with the trends of import substitution. The system approach was applied for a comprehensive study, elaboration of the development prospects and a comprehensive assessment of viticulture and winemaking production.

The material for calculations consists from both legal documents of Sevastopol and Crimea and financial statements provided by regional state and private wine enterprises, as well as restaurants and networks of wine shops. Material also includes regional agricultural indicators bounded with the unique geographical and climate conditions of Crimea. The sample includes all wine enterprises (5 biggest market players and 17 small wine companies, including terroir wineries) that operate legally in Crimea with an emphasis on the main market players. At the final stage, SWOT analysis of the viticulture and wine industry of the Crimea was applied for indicating the advantages and disadvantages of Crimean wine market, including the quality of product and busyness making conditions. 


\section{Results}

The integrated system of viticulture management in the region is represented by three main blocks:

- legislative and regulatory block, represented by international, state and regional standards;

- organizational and economic block, including the laying of the vineyard, zoning of the territory, optimization of placement and selection of the range of varieties, organization of production;

- agro-technological block, which includes pruning and the formation of bushes, maintenance and tillage, irrigation and fertilizing of vineyards, protection of vineyards from diseases and pests.

Russia's experience shows that the wine market is dominated by three criteria for competitiveness: the product quality, its consumer price and the range that reflects consumer preferences (Cicia, Cembalo, Del Giudice, \& Scarpa, 2013). At the same time, the indicators such as quality and consumer price are directly dependent on the technology of viticulture, as well as the totality of their subsystems, since in the cost structure for the production of one liter of wine, the cost of raw materials (grapes) is more than $50 \%$, and the productivity of plantings is the basis of the production of high-quality wines, identified by name and origin.

The wine market makes demands not only to the production of grapes (raw materials), but also to the efficiency of the technologies of its cultivation, which, in turn, is determined by the basic elements of the agro-technological block (grape management system, planting scheme, bush form, soil maintenance system, irrigation, fertilizing the plantings). Here, special attention is paid to such basic elements as zoning of the territory, selection and optimization of grape varieties. This is due to the fact that errors in the choice of basic elements lead to serious costs for compensating for the missing favorable factors for the production of grapes of the required quantity and quality.

Thus, it can be stated with absolute certainty that the wine market puts forward its own, rather stringent requirements for the production of grapes and the effectiveness of cultivation technologies, among which the main ones are noted:

- reducing the costs of grape production;

- yield in the amount, providing its condition at a price comparable to the limitations in the self-cost structure of the wine products;

- availability of varieties that provide the exclusive superiority of the produced wine.

An important indicator of the efficiency of grape production is its cost, which is formed in the process of production and circulation. In this regard, the following can be identified as the main stages of studying the production activities of enterprises in the industry:

- study of the raw material base;

- assessment of changes in production volumes, self-costs and sell prices for grapes;

- determining the influence of these factors on the competitiveness of products;

- study of sales markets for grapes;

- study of demand, taking into account the range of products.

From the point of view of socio-economic geography, a cluster can play the role of a promising viticulture and winemaking territorial system, which is a highly specialized, fairly stable market system, including complementary organizations and enterprises that are territorial in nature, since viticulture and winemaking are inseparable from a certain territory and their products are unique to each locality.

The cluster model is considered to be more dynamic and flexible, providing a more reliable system of connections, in contrast to the traditional system of the agro-industrial complex. This is due to the nature of the control and the level of interaction between the members of the system. Thus, in contrast to the agro-industrial complex, where clear and regulated relations are established between the participants with clear and planned management from the center, both regulated and non-systemic relations take place in the clusters. Exactly at the local level, the clusters provide a more reliable system of connections compared to the agro-industrial complex (Timirgaleeva \& Talanov, 2015).

However, one should not exclude the advantages of state regulation of the activity of the viticulture and winemaking subcomplex of the agro-industrial complex.

Recently, in the Crimea, to a certain extent, attention has been weakened to the most important elements of the organization of grape plantations - zoning of the territory, selection and optimization of the placement of the range of varieties (Mazurenko, 2015). 
Today, in the Crimean Federal District, a promising range of varieties is determined for each area of grape cultivation. The purpose of selection of varieties and optimization of their placement is the highly efficient use of the genetic potential, the most complete involvement in the production process of the resource, natural potential of the places of cultivation, reduction of costs for its cultivation, obtaining a stable and high-quality crop for fresh consumption and industrial processing.

The range of varieties is selected taking into account the conformity of its genetic characteristics to the conditions of the growing environment, requests from the processing industry and the conjuncture of the consumer market of grapes and wine.

Winemaking in the Crimea has existed for more than two thousand years. This industry in the area of the modern federal city of Sevastopol was developed in Chersonese, as well as the Genoese colonies. Prince Potemkin immediately drew attention to the development of winemaking in the Crimea; he took measures to plant almost the entire submontane area with vineyards, and the creation of a state winemaking school in Tavrida was recognized as useful. These provisions were approved by Emperor Paul I on February 13, 1798.

Sevastopol has a very interesting geographical position: it is located almost in the middle between the North Pole and the equator. Its latitude belt is the same as that of northern Italy and southern France (Unauthored, 2015), while it is located on the border of the steppe and mountain Crimea.

- The enterprises of the wine business, located in the federal city of Sevastopol, are explored. The authors allocated 11 names of enterprises, among which the following were marked as enterprises - the producers of wine, and some particularly large warehouses, tasting rooms and shops specializing in wine. The economic activities of the five manufacturing plants, the names of which are known outside of Sevastopol and the Crimean Peninsula, are also analyzed. These are the 'Inkerman' plant, 'Sevastopol Factory of Sparkling Wines', the 'Zolotaya Balka' plant, the winery in the Belbek Valley - 'Alkadar' plant and the production complex 'Satera' (Figure 1).

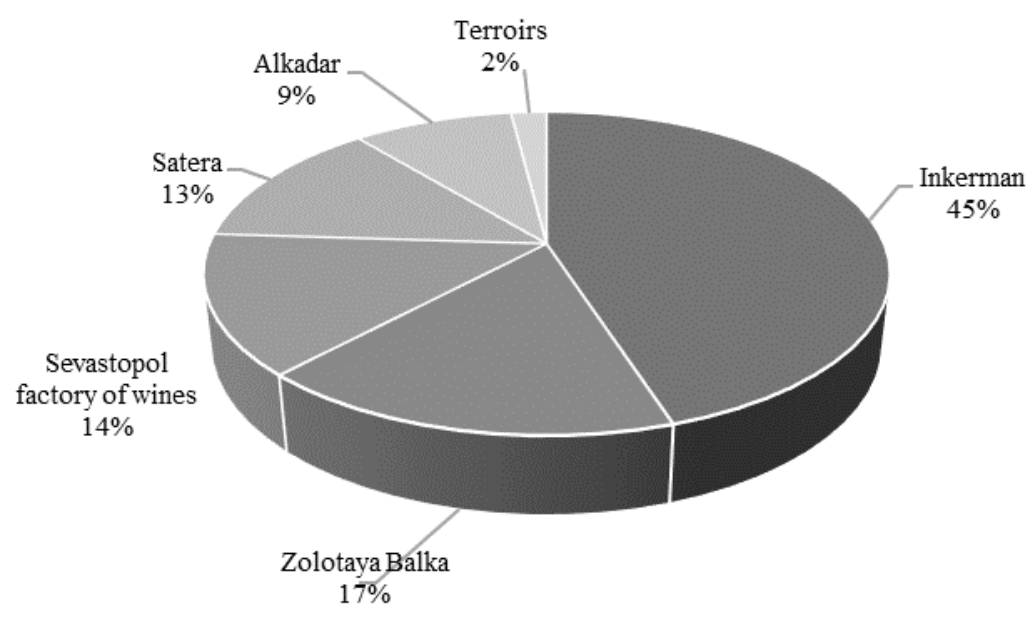

Figure 1. Market share of the wine business enterprises in the Sevastopol Region (\%)

Calculated based on data of Ministry of Economic Development of Republic of Crimea (2016).

In the region, there are enterprises and other areas of activity - wholesale stores, warehouses, and restaurants with a long history of doing business in this industry. The largest ones are noted here: the trademark 'Balashov', the specialized store of the Crimean wines 'Pogrebok', the cafe 'Le Terroir', the restaurant 'Wine Room', etc. Based on the research of the data presented in wide access, the following table of the percentage ratio of the large enterprises of the wine business in the region was compiled (Table 1). 
Table 1. Percentage ratio of the large enterprises of the wine business in the Sevastopol Region

\begin{tabular}{llc}
\hline \multicolumn{1}{c}{ Types of enterprises } & $\begin{array}{c}\text { Number in the } \\
\text { region }\end{array}$ & $\begin{array}{c}\text { Market share } \\
\text { in the } \\
\text { region, } \%\end{array}$ \\
\hline $\begin{array}{l}\text { Wine production plants (incl. sparkling and champagne ones), tasting rooms } \\
\text { with them }\end{array}$ & 5 & 45 \\
State farms and agricultural companies & 2 & 18 \\
Specialized wine stores & 2 & 18 \\
Specialized restaurants & 1 & 9 \\
Wine warehouses & 1 & 9 \\
Total: & 11 & 100 \\
\hline
\end{tabular}

Calculated based on data of Ministry of Economic Development of Republic of Crimea (2016).

Winemaking in Sevastopol is experiencing a new stage of development. Terroir wine is becoming more and more popular - the one created at the same place where the grapes from which the wine was made are grown. And more and more of these wines appear in the region.

Terroir is a combination of geological and climatic conditions, as well as many other characteristics of the area, which have a direct impact on the taste and aroma characteristics of the final product. For a wine with a potential that can be kept in a bottle for several decades, it matters what the soil in this area is, how much precipitation there was and what was the value of the height above the sea level and the temperature regime. The exposure of the slopes (angle of incidence of sunlight), the sum of the annual temperatures and the proximity of the reservoir is quite important (Van Leeuwen \& Seguin, 2006). In total, about 40 private winemaking companies were registered (for 2014), but the authors note the two largest elite wineries 'Uppa Valley', 'Alma Valley' - terroir wine, due to limited production capacity, is always in the segment of elite goods. Specialized boutiques and restaurants mainly work with it (Mazurenko, 2015).

The idea of modern terroir winemaking: each land is unique, so the grapes of the European varieties, transferred to local soil, will reveal its potential in a completely different way than in its homeland. The idea is associated with it regarding the separation of the region - the federal city of Sevastopol into a separate category of winemaking lands with a protected appellation of their origin - protected designation of origin - PDO (similar to the French appellation) (Van Leeuwen \& Seguin, 2006). The areas with a special, fertile climate also include the Alma Valley, the valleys of the Chernaya, Kacha and Belbek Rivers, which are famous for their dessert and dry wines.

Among the foreign private enterprises of the wine business, there is also an interest in the Sevastopol Region. Due to the rich mineral soil, grapes on this land take root deeply, absorbing useful substances from the depths and accumulating them in a berry. According to experts (Cicia et al., 2013), for the wine with high potential, a vine does not require additional watering and special fertilizers. Winemaking in the classical sense is the proper cultivation of the soil in natural conditions, without artificial irrigation and fertilizers.

In Sevastopol, a completely unique (in the scale of Southern Russia) wine is also produced - the biodynamic one. It is created without the use of additional chemicals, in other words, the 'wild' yeast for the manufacture of such wine is used - those that are on a berry itself. Due to this, the wine acquires a distinctive aroma and taste of the area where it was produced.

In addition, among the grape varieties, autochthonies, or 'aborigines', are particularly interesting. These varieties grow in this region. In the Crimea, over 200 of them exist. But not every one of them can become high-quality wine - it will take a long time to explore their potential for winemaking. The following are known among these varieties: Ekim-Kara, Javat-Kara, and Kefesia.

Currently, in the range of varieties of farms, it is recommended to have $70 \%$ of technical and $10 \%$ of universal varieties, $40 \%$ with uncolored and $60 \%$ with colored berries, $20 \%$ of table wine. This ratio has a certain proportion of convention. It is determined most accurately by the demand of the consumer market. For example, in the Crimea as the zone of development of the tourist business and the concentration of tourists, the demand for table grapes is increasing. Bearing this in mind, it is possible to recommend to increase this ratio in the direction of table varieties in the Crimea (up to 25\%) while reducing the share of universal varieties (up to 5\%) and maintaining the share of technical varieties at 70\% (Mazurenko, 2015). 
Moving from the general part of the research to the analytical one, the authors note the features of the five largest enterprises of the wine business of the federal city of Sevastopol.

1. 'Inkerman Vintage Wine Factory' LLC. It should be noted that Inkerman is the extreme south-west of the Crimean Peninsula, the territory of the city of Sevastopol. The winery was established in 1961 on the basis of the workings of building chalk stone in a closed way. Due to the cutting out the stone, which was used for post-war reconstruction of Sevastopol, in the mountains, the galleries were formed at a depth of 5-30 meters with almost constant temperature (from 12 to 15 degrees) and humidity - ideal conditions for organizing wine cellars. The plant has 55 thousand square meters of the basement area. The capital of the company is formed as follows: $40 \%$ belong to the Finnish holding company 'Hartwall Capital', 60\% - to Cyprus offshore companies (Erdavletov, Artemev, \& Koshkimbaeva, 2011) with different beneficiaries.

This is one of the largest enterprises of classical winemaking in the Crimea, where vintage wines are produced (up to 4.5 million bottles a year). Wine materials for their production are supplied by more than 20 Crimean farms for the processing of grapes. The gold fund of the Inkerman cellars is oak packaging. The plant has 700 barrels (capacity from 5,000 to 20,000 liters) and 7,000 casks (capacity from 300 to 1,000 liters).

During aging in oak, complex physicochemical processes take place in wine; the wine acquires noble tones of aging. The average period of exposure is two years for table wines and three years for strong and dessert ones (Erdavletov et al., 2011). During this period, the plant specialists regularly monitor the condition of the wine. This is practically the only company that produces a full range of vintage table wines from the European and local grape varieties.

Based on the data on the number of manufactured products per year (Table 2), a chart is drawn up (Figure 2).

Table 2. Number of manufactured products per year

\begin{tabular}{ll}
\hline \multicolumn{1}{c}{ Name of the enterprise } & \multicolumn{1}{c}{$\begin{array}{c}\text { Volume of manufactured products } \\
\text { (thousand bottles/year) }\end{array}$} \\
\hline "Inkerman Vintage Wine Factory" LLC & 4800 \\
Agrofirm "Zolotaya Balka" LLC & 1750 \\
State enterprise "Sevastopol winery" & 1500 \\
Winemaking company "Satera" LLC & 1420 \\
Winery "Alkadar" - CJSC named after Sophia Perovskaya & 850 \\
Other small wine companies, including terroir wineries & 230 \\
Total for the Sevastopol Region: & 10,550 \\
\hline
\end{tabular}

Calculated based on data of Ministry of Economic Development of Republic of Crimea (2016).

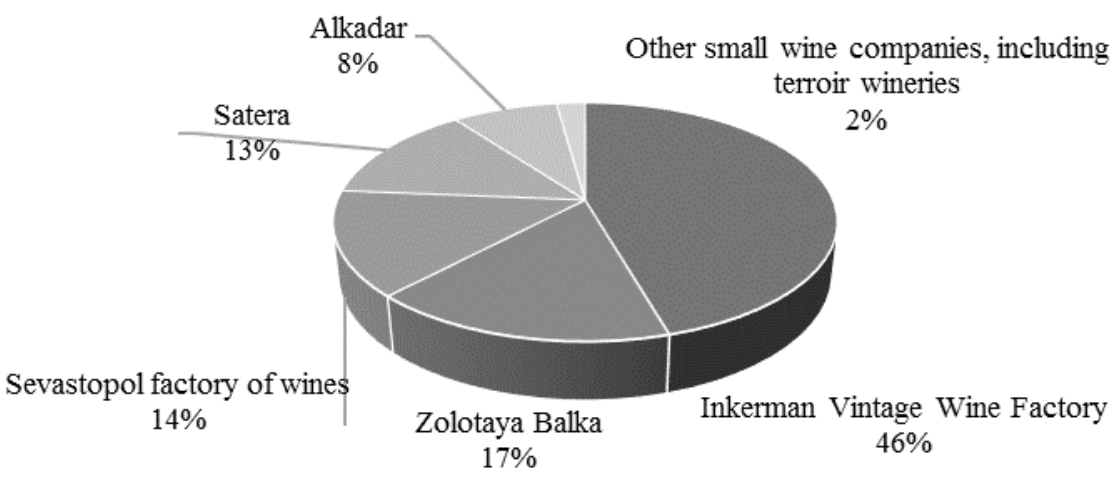

Figure 2. The number of manufactured products in the Sevastopol Region (in \%)

Calculated based on data of Ministry of Economic Development of Republic of Crimea (2016). 
2. The agrofirm 'Zolotaya Balka' LLC is one of the oldest domestic plants for the production of sparkling wines. The vineyards of the agrofirm are located on the area in one and a half thousand hectares in the vicinities of Balaklava and Sevastopol. According to the parameters of the relief, soil conditions, heat and moisture, the sufficiency of solar radiation, the area of the location of the vineyards of this agricultural company is called 'Crimean Champagne'.

It is in the western part of the submontane Crimea that the best grape varieties are cultivated for the production of table and Muscat wines. Every year, the agricultural company 'Zolotaya Balka' produces more than 4 thousand tons of table grapes, 4.5 million bottles of 'champagne' and sparkling wines. Given the current range, only sparkling wines produced in AOC (Appellation d'origine controlee) Champagne using the traditional method of making sparkling wines (méthode champenoise), the production which is strictly controlled by the AOC Champagne, have the right to be called champagne. Champagne can be made only from six grape varieties. The following varieties are most often used in the production of champagne: Pinot Noir, Pinot Meunier, Chardonnay, Pinot Blanc, Petit Meslier, Arbani.

The company specializes in the production of sparkling wines. Like champagne, these wines have frothy and sparkling properties, but differ in the specifics of the bouquet, taste, associated with the characteristics of the grape variety used in production. In addition, 'Zolotaya Balka' produces table and strong wines. The capacity of the agrofirm park today is 560 thousand bottles per month.

3. State enterprise 'Sevastopol Winery'. Founded in 1936, it produces high-quality sparkling wines. The unconditional masterpiece of Sevastopol wine-makers is sparkling wines, unique in their technological and gastronomic features - 'Muskat Sparkling' and 'Sevastopol Sparkling'. Specialists of the plant keep the peculiarities of the production of these wines in strict secrecy - such technology is not found anywhere else in the world. Muscat sparkling wine was awarded the Grand Prix Cup in 1965 at an international competition in Montreal.

Products of SE 'Sevastopol Winery' were awarded more than 20 golden and silver medals. For seventy years, the plant has been the leader of the Crimean market of sparkling wines: more than $60 \%$ of sales in the Crimea is 'Sevastopol Champagne', which is produced in accordance with the strict requirements for the production of sparkling wines. Moreover, over 30\% of the plant's products are exported to the USA, Canada, Germany, Switzerland, Ireland, Latvia, Denmark, Israel, and other countries. Up to 1.5 million bottles are produced annually.

4. Winery 'Alkadar' CJSC named after Sophia Perovskaya has its history since the beginning of the 19th century, when the lands of the village of Lyubimovka belonged to the noble family Perovsky, from which the modern landmark of local winemaking begins. The first planting of vineyards in the estate, called 'Primorsky', was made by Nikolai Ivanovich Perovsky in 1834. After 12 years, the wines produced in Primorsky received positive reviews at the All-Russian Exhibition in Abrau-Durso.

Now the company processes tens of thousands of tons of grapes per year and sells millions of liters of high-quality wine materials purchased by plants of secondary winemaking, including the enterprises of the New World, Inkerman, and until recently - Artyomovsk and Kharkov (Ukraine).

At the beginning of the 20th century, winemakers-specialists noticed that grapes growing on the slopes of the Belbek Valley, receiving a special amount of solar radiation and moisture, are perfectly suited for the production of champagne and sparkling wine, but only in mid-2012 the first sparkling wine was laid in the Stahl cellars at the plant 'Alkadar'.

Now the state farm named after Sophia Perovskaya processes 800 hectares of vineyards, where technical varieties intended for the production of vintage and sparkling wines grow. These are Cabernet, Chardonnay, Aligoté, Pinot, Rkatsiteli, Riesling, and others. There are also extensive gardens and essential oil lavender culture. It should be noted that this plant produces a limited number of 'Beaujolais', meaning Beaujolais nouveau (fr. Beaujolais nouveau 'new Beaujolais') - a variety of fresh French wine produced from the Gamé grape variety in the historic region of France Beaujolais (Burgundy). In the Crimea, it is produced from acclimatized grape varieties in accordance with the French tradition, the so-called young wine, which ripens for only three days. In the Crimea, it is produced from acclimatized grape varieties in accordance with the French tradition. For the Crimea, it is a unique line of wines.

5. The winemaking company 'Satera' LLC is the youngest plant for the production of wines, the products of which are mainly focused on the premium class of consumers. The production facilities of the enterprise are located in the village of Dolinnoye (Kachinskaya Valley, Bakhchisarai District). The basis for the plant was a cannery, founded in 1978, owned by the state farm-millionaire 'Pobeda'. The plant began to develop as a winemaking company in the early 2000s. After 2003, 'Satera' acquired land for new vineyards in the Kachinskaya Valley - a total of 49 hectares, which are two single blocks -20 hectares and 29 hectares, which, in turn, are divided into even smaller areas (called 
'cards' in accordance with the Soviet tradition), planted with certain grape varieties.

17 grape varieties do not grow in large blocks, but are defragmented across the entire vineyard (thus, the winemaker has a good opportunity to experiment with different styles so as not to depend on the vagaries of nature and find the best incarnation of the varieties). The soils of the area are diluvial-carbonate and are deposits of rock formations and sea rocks with a high content of chalk stone. In 2015, it was planned to process 10,000 tons of grapes at the production facilities of 'Satera' and produce four lines of wines: available wines 'Krim', varietal wines - 'Satera', wines from medium to premium segment 'Esse' and a new line of premium wines 'Kacha Valley'. In 2014, the plant laid 70,000 bottles of new wines. The average production volume is 1.4 million bottles per year.

Based on the data obtained in the course of researching the range of specialized wine stores, a histogram was created, displaying the segmentation of the wine market into classes-categories of manufactured products. The basis of this method was the correlation of the company's production volume with the percentage of products of a separate class in the network of stores 'Specialized Store of the Crimean Wines 'Pogrebok' (Figure 3).

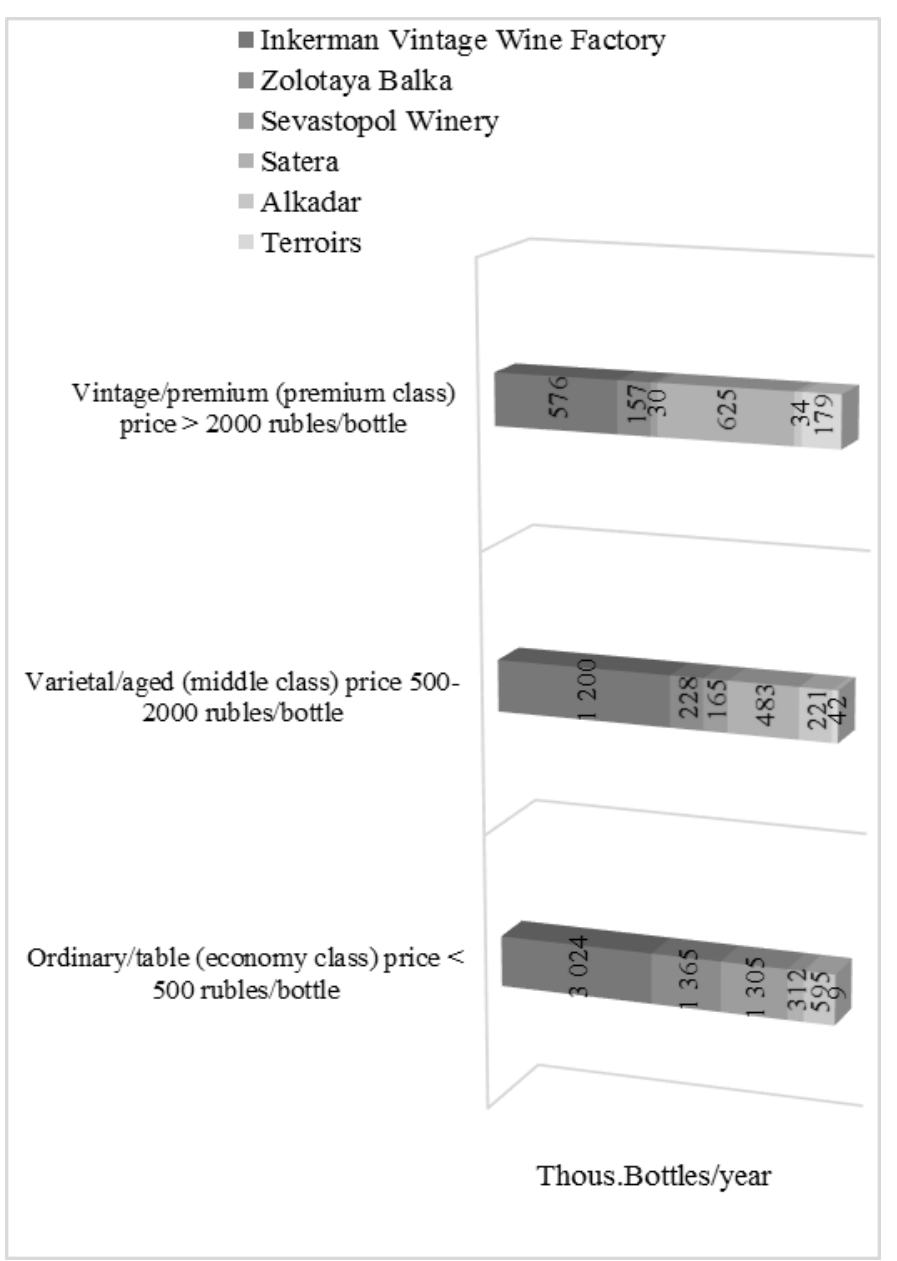

Figure 3. Segmentation of the market of wine business enterprises of the Sevastopol Region by classes (thousand bottles/year)

Compiled based on a study of the assortment of specialized wine stores of Sevastopol (Ministry of Economic Development of Republic of Crimea, 2016).

An analysis of the pricing policy of these enterprises showed that, mainly, these subjects used the strategy of flexible prices and only the winemaking company "Satera" LLC chose for itself the high price strategy - "skimming the cream off". The same pricing strategy is implemented by small winemaking companies in the region, including terroir ones (Table 3). 
Table 3. Pricing policy of enterprises of the wine business of the Sevastopol Region

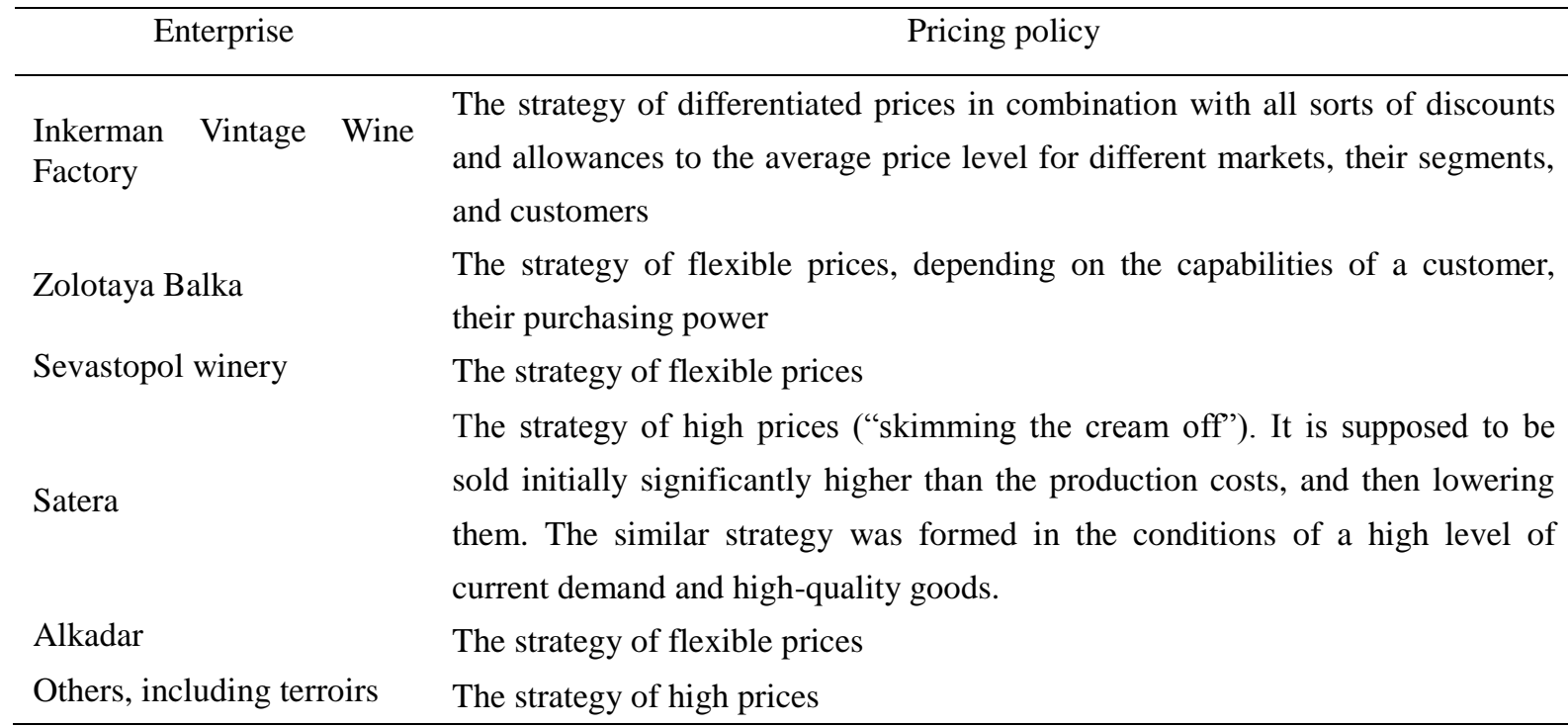

Compiled on the basis of the sales market for wines in the "Pogrebok" liquor stores, restaurants "Wine Room" and "Le Terroir" (Analysis management)

However, it should be noted that the regulation and pricing of grapes is far from perfect. They are very low and mostly do not compensate enterprises for the costs of production, especially since the cost of fertilizers, machinery, means of protecting vineyards from pests and diseases, fuel and lubricants significantly increases every year. At the same time, the prices of grapes remain virtually unchanged. As a result, viticulture from the profitable industry, which it was before, turned into low-profitable and sometimes unprofitable (Timirgaleeva \& Talanov, 2015).

In connection with this, many farms destroy vineyards and cultivate more profitable sunflower and wheat in their place. At the same time, laying one hectare of new vineyards and growing them before entering into fruiting requires 180-240 thousand rubles of capital investment. Accordingly, the prices of grapes should provide producers with a fairly high (compared to annual crops) level of profitability. The profitability of this industry should be about $45-55$ percent.

The study showed that the current state of the Russian wine market is characterized by a significant excess of the consumption of wine products over the volumes of domestic production, which entails dependence on foreign suppliers of raw materials. This conclusion is a promising direction for further research in the formation of a strategy for the development of global and regional wine markets. The identified trends in the Crimean winemaking industry in recent years are the basis for developing competitive strategies that give the region the opportunity and the prospect of increasing its own production volumes of wine materials and wine, taking into account the above-noted prerequisites for the development of the industry.

Nevertheless, it is necessary to note the fact that the viticulture and winemaking industry of the Crimea has a number of weaknesses and threats; however, compensation is possible due to the presence of advantages and opportunities.

SWOT analysis of the viticulture and wine industry of the Crimea.

Advantages:

(1) Extensive volume of the domestic market of the Russian Federation.

(2) Favorable soil and climatic conditions (terroir).

(3) Viticulture and winemaking school with a historical past and world fame.

(4) Availability of existing, including private industries.

Disadvantages:

(1) Nearly $70 \%$ of vineyards are over 20 years old and thinned by $20-40 \%$.

(2) Regression from foreign wine materials. 
(3) Depreciation of fixed assets, outdated production technologies, lack of qualified personnel.

(4) Narrow logistic system.

(5) The insignificant popularity of classical wines and the lack of rebranding in the Crimean and Sevastopol wines and, as a result, the lack of demand for products both in domestic and foreign markets.

(6) A technical, scientific and educational base that does not meet modern requirement.

Opportunities:

(1) The vast amount of soils, suitable for vineyards.

(2) Positive growth of the culture of wine consumption in Russia.

(3) Demand for new items in an affordable price segment in the world markets (decline in the prevalence of recognized centers and varieties of wine).

(4) Active actions of the state in relation to the development and maintenance of the economy of Crimea.

Threats:

(1) A large amount of illegal and falsified production of wine products.

(2) Growth in consumption of low-alcohol beverages such as beer and cider.

(3) The rapid development of viticulture and wine-making industries in the neighboring countries - Uzbekistan, Moldova, Georgia, Azerbaijan.

(4) Weak attractiveness of the industry for investment.

\section{Discussion}

The monitoring of the wine market of the federal city of Sevastopol revealed the presence of a wide variety of services and goods in the field of winemaking, represented in the region, showed the potential of the resources of viticulture and made it possible to substantiate the need to form a model of further interaction of wine business enterprises based on clustering, which is based on the presence of partnerships between the subjects of the cluster. This mechanism will give a new impulse to the development of viticulture and winemaking production, sales markets of the product, will expand the possibilities of attracting new investments, more effectively use the resource, scientific, technical and production potential of the region.

Thus, the analysis of the specificity of the viticulture and winemaking industry of the Republic of Crimea and the federal city of Sevastopol showed that the region has all the resources to become the basis of import-substituting wine production in the Russian Federation.

The importance of the presented results is confirmed by the calculations, conducted when drafting the Federal Target Program for the Development of the Crimea and the Federal City of Sevastopol until 2020, which show that additional 10-12 thousand hectares in 10 years can satisfy the primary needs of the wineries of the Crimea in the qualitative grapes (Government of Sevastopol, 2014). Moreover, the formulated target key indicators of the results of the implementation of the strategy for the development of the viticulture and winemaking industry of the Crimean Federal District for 2014-2025 correlate with the results of the assessment of the potential of the viticulture and winemaking subcomplex of the agro-industrial complex of the federal Sevastopol and the proposed concept of the mechanism for the development of the industry (Legislative Assembly of the city of Sevastopol, 2015).

The formation of a wine cluster and the implementation of the idea of modern terroir winemaking in Sevastopol were proposed as part of the development of the industry in the direction of elite winemaking and the creation of a 'wine province', which is also provided for by the concept of regional development and relies on small wineries of the full cycle. This will increase the investment attractiveness of the region, expand production and sales markets for wine products, and more efficiently use the resource potential of the region.

The promising areas of continuing the research are as follows:

- the need to change the policy of promoting the products to the market;

- the formation of a marketing strategy taking into account the fact that the Russian wine market over the past few decades has not only occupied stable positions, but has also been segmented in a certain way;

- the need to restore old and search for new sales markets for grapes and the products of its processing;

- legislative consolidation of the long-term lease of land for the creation of perennial plantings; 
- adoption of sectoral laws aimed at reviving the industry, forming and developing its potential;

- development of measures to ensure import substitution in the Russian market in the amount of not less than $20 \%$ of Russia's need for grapes of table varieties and not less than $30 \%$ of Russia's demand for wine materials, used for the production of winemaking products.

The result of the implementation of the proposed directions will be an increase in the share of the products of viticulture and winemaking industry in the structure of the gross regional product of the Republic of Crimea and the federal city of Sevastopol.

The results obtained in the course of the study can be the basis for the formation of projects for implementing the program for the socio-economic development of the city of Sevastopol until 2030.

\section{Conclusion}

The analysis of the performance indicators of the largest enterprises showed that these farms can and should become the basis of import-substituting production, which, in turn, will contribute to the development of the industry in the region and incur interest in the Crimea in the domestic and international market within the framework of wine tourism. In addition, if the 'Strategy for the Development of the Industry of Viticulture and Winemaking in the Republic of Crimea and the Federal City of Sevastopol for the period 2014-2025' is implemented, this region will have all the prerequisites to become one of the most successful winemaking provinces in the world.

In conclusion, it should be noted that the revival and development of the labor-intensive viticulture and winemaking industry of the Crimea will contribute to the formation of new jobs for the population living in rural areas, which will make it possible, in addition to all other positive effects, to reduce social tension in the region.

\section{References}

Castillo-Valero, J. S., \& García-Cortijo, C. (2016). Price adjustment in world wine markets: A cointegration analysis. Agriculture and Agricultural Science Procedia, 8, 176-185.

Cicia, G., Cembalo, L., Del Giudice, T., \& Scarpa, R. (2013). Country-of-origin effects on Russian wine consumers. Journal of Food Products Marketing, 19(4), 247-260. https://doi.org/10.1080/10454446.2013.724369

Erdavletov, S. R., Artemev, A. M., \& Koshkimbaeva, U. T. (2011). Ethno-tourism as a factor for regional and local development. Geographical Bulletin. Tourism and Local Studies, 4, 77-81. Retrieved from https://elibrary.ru/item.asp?id=17825964

Fleming, E., Mounter, S., Grant, B., Griffiths, G., \& Villano, R. (2014). The New World challenge: Performance trends in wine production in major wine-exporting countries in the 2000s and their implications for the Australian wine industry. Wine Economics and Policy, 3, 12-22. https://doi.org/10.1016/j.wep.2014.12.002

Gilinsky, A. Jr., Newton, S. K., \& Vega, R. R. (2016). Sustainability in the Global Wine Industry: Concepts and cases. Agriculture and Agricultural Science Procedia, 8, 37-49. https://doi.org/10.1016/j.aaspro.2016.02.006

Government of Sevastopol. (2014, November 27). Decree on the approval of the State program of the federal city of Sevastopol 'Development of agriculture and processing industry of the federal city of Sevastopol for 2015-2020' No. 511. Retrieved from http://crimea.regnews.org/doc/mq/im.htm

Hojman, D., \& Hunter-Jones, P. (2012). Wine tourism: Chilean wine regions and routes. Journal of Business Research, 65, 13-21. https://doi.org/10.1016/j.jbusres.2011.07.009

Legislative Assembly of the city of Sevastopol. (2015, April 8). The concept of the development of winemaking of the federal city of Sevastopol of the Association of Winegrowers and Winemakers 'Sevastopol'. Retrieved from https://sevzakon.ru/3240/koncepcii_razvitiya_vinodeliya/3264/3265/

Mariani, A., Pomarici, E., \& Boatto, V. (2012). The international wine trade: Recent trends and critical issues. Wine Economics and Policy, 1, 24-40. https://doi.org/10.1016/j.wep.2012.10.001

Mazurenko, N. A. (2015). Istoriya vozdelyvaniya vinograda Muskat belyi i ispol'zovanie muskatnykh sortov v vinodelii [History of cultivation of grapes Muscat white and Muscat varieties use in winemaking]. Nauchnaya Diskussiya: Innovatsii v Sovremennom Mire [Scientific Discussion: Innovations in the Modern World], 8, 42-49.

Ministry of Economic Development of Republic of Crimea. (2016, January). Management of the analysis of socio-economic development. Results of the socio-economic development of the Republic of Crimea for 2015. Retrieved from http://minek.rk.gov.ru/file/File/minek/2016/analiz_soc_ek/macro/macro_2015_new.pdf

Timirgaleeva, R. R., \& Talanov, V. Ya. (2015). Use of systemic approach to the development of the strategy of an 
enterprise. Relevant problems of the economy of modern Russia, 2, 365-370.

Unauthored. (2015, December 11). Revival of viticulture and winemaking in the Crimea. Innovative technologies in agrarian production and in marketing. In To find. To share. To teach. Retrieved from http://www.slideshare.net/bewinemaker/ss-42521086

Van Leeuwen, C., \& Seguin, G. (2006). The concept of terroir in viticulture. Journal of Wine Research, 17(1), 1-10. https://doi.org/10.1080/09571260600633135

Velikova, N., Murova, O., \& Dodd, T. H. (2013). Emerging wine market in the Dominican Republic: Consumer market analysis. Wine Economics and Policy, 2, 76-84. https://doi.org/10.1016/j.wep.2013.07.001

Vlachos, V. A. (2017). A macroeconomic estimation of wine production in Greece. Wine Economics and Policy, 6(1), 3-13. https://doi.org/10.1016/j.wep.2017.03.001

Wittwer, G., Berger, N., \& Anderson, K. (2003). A model of the world's wine markets. Economic Modelling, 20, 487-506. https://doi.org/10.1016/S0264-9993(01)00095-5 